WIDER Working Paper 2018/105

Socio-economic development in South Asia

The past 50 years

S. R. Osmani*

September 2018

United Nations University World Institute for Development Economics Research 
Abstract: The story of South Asia is a topsy-turvy one. Soon after independence from British rule, the region seemed to have a much better prospect than many other parts of the Third World; the prospects soon dimmed, however, as South Asia crawled while East and Southeast Asia galloped away. But a large part of the region seems finally to have turned a corner and is looking forward to a much better future-in terms of both growth and human development-than was deemed possible at the time Asian Drama was written. This paper describes and explains this story in terms of the economic strategies and political economy of the region and also looks ahead to identify the major challenges that remain-focusing on Bangladesh, Pakistan, Sri Lanka, Nepal, and Bhutan.

Keywords: South Asia, growth, poverty, inequality, human development JEL classification: O11, O40, O53, I31

Acknowledgements: The author is deeply grateful to Deepak Nayyar, an anonymous referee, and participants at two seminars in Hanoi and Shanghai for extremely valuable comments on earlier drafts of the paper. The responsibility for any remaining errors and shortcomings rests solely with the author.

* Department of Accounting, Finance and Economics, Ulster University, United Kingdom, sr.osmani@ulster.ac.uk.

This study has been prepared within the UNU-WIDER project on 'Asian Transformations: An Inquiry into the Development of Nations'.

Copyright (C) UNU-WIDER 2018

Information and requests: publications@wider.unu.edu

ISSN 1798-7237 ISBN 978-92-9256-547-3 https://doi.org/10.35188/UNU-WIDER/2018/547-3

Typescript prepared by Joseph Laredo.

The United Nations University World Institute for Development Economics Research provides economic analysis and policy advice with the aim of promoting sustainable and equitable development. The Institute began operations in 1985 in Helsinki, Finland, as the first research and training centre of the United Nations University. Today it is a unique blend of think tank, research institute, and UN agency — providing a range of services from policy advice to governments as well as freely available original research.

The Institute is funded through income from an endowment fund with additional contributions to its work programme from Finland, Sweden, and the United Kingdom as well as earmarked contributions for specific projects from a variety of donors.

Katajanokanlaituri 6 B, 00160 Helsinki, Finland

The views expressed in this paper are those of the author(s), and do not necessarily reflect the views of the Institute or the United Nations University, nor the programme/project donors. 
This paper tells the story of the South Asian economy (excluding India) in the last 50 years. Soon after independence from British rule around the middle of the last century, the region seemed to have a better prospect than many other parts of the Third World. In the event, however, South Asia crawled while the neighbouring East and Southeast Asia ${ }^{1}$ galloped away. In fact, in the 1970s, soon after Gunnar Myrdal had finished writing his Asian Drama, South Asia (including India) plunged into a crisis that made future prospects look even worse than Myrdal had perceived. Nonetheless, after traversing a chequered path, a large part of the region seems finally to have turned a corner and is looking forward to a much better future than seemed possible at the time Asian Drama was being written. This paper describes and explains this story in terms of the economic strategies and political economy of the region-focusing on Bangladesh, Pakistan, Sri Lanka, Nepal, and Bhutan.

It ought to be recognized at the outset that, although South Asia has failed to keep pace with East and Southeast Asia, in absolute terms the region has made great strides in the last 50 years-in both economic and social spheres (see Table A1 in the Appendix). South Asia was among the most populous parts of the world at the time, and excessive population pressure was widely deemed to be a potentially serious obstacle to the region's socio-economic progress. After 50 years, the region remains among the most populous parts of the world, with more than a trebling of the population of the region as a whole. But the spectre of population explosion is no longer as haunting as it used to be. This is because the region has generally succeeded in bringing down the rate of population growth considerably. From an average of over 2.5 per cent per annum, population growth has come down to an average of about 1.5 per cent, the only exception being Pakistan, where population growth has slowed only marginally and still remains above 2 per cent. The slowdown in population growth was made possible by an unusually early demographic transition that is still ongoing in most of the region. With the exception of Pakistan, where the fertility rate is still high at 3.7, all the countries of the region are fast approaching the replacement fertility level of 2 .

Slowing population growth and respectable economic growth have together ensured that, despite more than a trebling of its population size, the region has experienced an improvement in living standards that did not seem possible 50 years ago. Per capita income has almost trebled in the region as a whole, life expectancy at birth has gone up from less than 50 years (except in Sri Lanka) to nearly 70 years, and enrolment at the primary level has become near universal (see Table A1).

This paper tells the story of how this progress was achieved and what challenges lie ahead. Section 2 sets out the background to the story by looking at the initial conditions, i.e. those that Myrdal would have observed in the 1960s. Section 3 provides an overview of the economic growth and structural transformation of the region over the 50 years since the writing of $A$ sian Drama. Sections 4 and 5 then attempt an analytical narrative of the major forces-including policies and exogenous factors - that underlie the growth process. Next, the record of performance in the spheres of poverty reduction and human development is discussed in Section 6. Finally, Section 7 offers some brief observations on the prospects of the region in the coming decades.

\footnotetext{
${ }^{1}$ East Asia here refers to the region classified by the World Bank as 'East Asia and Pacific (excluding high-income countries)' and the data are taken from the database of World Development Indicators.
} 
As the countries of the region embarked on the path of economic development around the middle of the 20th century, they naturally shared some common initial conditions, stemming from a common historical legacy, most notably nearly two hundred years of British colonial rule. ${ }^{2}$ At the time Myrdal began to study this region, a couple of decades after colonial rule had ended, he correctly observed that not much had changed in these shared initial conditions, except in one major respect-population growth had surged, making the already dire conditions even more so. This change, too, was shared by the region as a whole. Nonetheless, there were some important differences among the countries-stemming from cultural, geographical, and to some extent historical differences - that did have a significant bearing on their subsequent trajectories of development.

Nepal and Bhutan, being landlocked and having a rugged, mountainous topography, were geographically very different from the rest of the region. Their topography posed a serious potential hindrance to the development of agriculture and infrastructure, in particular. The same topography, however, also endowed them with a rich potential of hydropower, which they were to harness to great advantage in the years to come. In contrast, Bangladesh was a plain riverine land, whose soil fertility was regularly replenished by the rich alluvial deposits that came with the annual flooding of several mighty rivers and their numerous tributaries criss-crossing the entire landscape. The geography of Bangladesh made the pursuit of traditional rice-based agriculture especially convenient. This ease of subsistence agriculture came with a price, however: it induced a high level of human fertility, which-once mortality began to come down with the introduction of modern medical technology - translated into an exceptionally high population density. The riverine topography also made development of physical infrastructure especially difficult, in addition to making the country susceptible to excessive flooding and devastating tidal surges, which occurred from time to time, causing immense loss of life and crops. Pakistan had a combination of rugged mountains and plain land. While its plains were not as naturally fertile as those of Bangladesh, the Indus Valley Development Project, initiated during British rule, had endowed it with a rich network of modern irrigation, placing its agriculture at an advantage over all the other countries of the region. Sri Lanka, as an island economy, was geographically at the opposite pole of landlocked Nepal and Bhutan. Like Pakistan, it had a fair mix of rugged mountains and plain land, but the land was naturally fertile, blessed as it was with generous rainfall from a double annual monsoon. Unlike agriculture in the rest of the region, however, Sri Lanka's agriculture was not singularly oriented towards the production of subsistence crops (rice and wheat). Sri Lanka was unique in the region in having a predominance of plantation agriculture (mainly tea, followed by rubber and coconut), as a direct legacy of British colonial policy. In the early 1950s, plantation agriculture accounted for nearly 30 per cent of GDP and 70 per cent of agricultural value-added; in this respect Sri Lanka's economic structure was more akin to that of some of the Southeast Asian economies, such as Malaysia, than to her South Asian neighbours.

There were significant differences in the political sphere as well. Nepal and Bhutan were ancient kingdoms, ruled by powerful dynasties, which did not allow democratic freedom of any sort. The cost of unfreedom in the two countries was very different, however, owing to deep-seated religious and cultural differences. Nepal was a deeply caste-divided Hindu society, where the lower castes faced severe discrimination in all spheres of life-in some ways, more severe than even the worst cases of caste discrimination in India. Bhutan, in contrast, was a much more peaceful,

\footnotetext{
${ }^{2}$ Although Nepal and Bhutan were never colonized by India, they were not altogether immune from the economic and political consequences of British colonialism.
} 
homogeneous Buddhist society, where the general populace was largely content with meagre living in material terms, and the elite faced little resistance in maintaining its grip on both political and economic levers. While both these kingdoms were internally powerful, however, they were externally vulnerable, because of their small size and land-locked nature; and they responded to this vulnerability by forging very close political and economic relations with India.

Pakistan and Bangladesh, which were parts of the same country when Myrdal was writing, had a very different political and cultural disposition. There were stirrings of democracy following independence from colonial rule in 1947, but they soon dissipated as the country came to be ruled by military dictatorship within a decade of independence; and by the time Myrdal began to study this region in the 1960s, autocracy had become firmly entrenched. The underlying discontent at the loss of democratic freedom never disappeared at the grassroots level, however, especially in Bangladesh (East Pakistan, as it was then called), for which military dictatorship was tantamount to forceful subjugation of their people by the military junta of (West) Pakistan. Over time, the undercurrent of discontent was to culminate in an explosion of nationalist sentiment, which was eventually to lead to the break-up of Pakistan and the emergence of Bangladesh as an independent nation in 1971. But the legacy of prolonged military rule had already done lasting damage to the polity in both countries, especially in Pakistan, as military rule was repeatedly re-imposed under various pretexts. Bangladesh has succeeded somewhat better in removing the shackles of autocracy in recent years, practising parliamentary democracy since 1990-albeit in a deeply flawed fashion-but Pakistan continues to be haunted by the recurrence of military rule every time the prospect of democracy raises its head.

The two countries also differ in some cultural attributes that have played a significant role in shaping the divergent paths of certain aspects of their socio-economic development. Although both are predominantly Muslim majority countries, religious and cultural attitudes differ sharply. Pakistan practises an especially conservative version of Islam, which tends to inhibit progress in important dimensions, such as female education, population control, the emancipation of women from centuries of patriarchal domination, and the emancipation of the masses as a whole-both men and women-from the bane of religious fundamentalism. In contrast, Bangladesh has historically adopted a more liberal orientation, which has made its people more open to accepting norm-changing behaviour, not only with regard to female education, women's autonomy, population control, and so on, but also in other dimensions of behaviour-such as those relating to health and hygiene.

Among all the countries under review here, Sri Lanka was initially the most advanced in terms of success in forging democratic institutions. The practice of limited self-rule that the British had initiated in the 1930s had already instilled a culture of democratic practice even before the British left, and, by the time Myrdal was writing, democracy had taken a firm hold in Sri Lanka, with the two major political parties alternating in power through a largely fair electoral process. There was trouble ahead, though, as the eruption of violent conflict between the majority Buddhist Sinhalese community and the minority (but sizeable) Hindu Tamils threatened to destroy the fabric of the society. Yet the country never succumbed to the kind of explicit military takeovers that became a recurrent pattern in Pakistan, and to a lesser extent in Bangladesh.

Apart from a more democratic polity, the initial conditions of Sri Lanka differed from those of the rest of the countries in several other important respects. Most significantly, Sri Lanka was well ahead of the rest (including India) in terms of per capita income. This advantage was owed almost entirely to its plantation economy, which had enabled Sri Lanka to gain handsomely from commodity booms even before it became politically independent; after independence, the advantage was further reinforced by the Korean boom. Sri Lanka was also way ahead in terms of human development: its achievements in health and education were exceptional—well above the 
levels obtaining in other countries with similar per capita income. On the whole, Sri Lanka's initial conditions could be said to have been not only the best in the region but also among the best in Asia as a whole.

Despite many differences in the initial conditions noted above, the majority of the countries shared one common initial condition that was fundamental to their subsequent transformation. This commonality lay in the choice of development strategy. Inspired by the example of India, they adopted the then popular strategy of economic planning in which the state was expected to play a predominant role in guiding the process of economic development. Like India, they started by preparing five-yearly development plans; and most of the characteristic features of early Indian planning-such as emphasis on state control of the 'commanding heights' of the economy, strong scepticism about the efficacy of market mechanism, and heavy reliance on import substitution as the strategy of industrialization-were also present in the planning strategy of Pakistan (including Bangladesh), Sri Lanka, and Nepal.

There were a couple of significant exceptions, however. While Sri Lanka did follow in the footsteps of India by adopting a state-led development strategy, it continued at the same time to sustainand indeed strengthen - its unique welfare state policies, which were inherited from the terminal years of the colonial times. The other exception was Bhutan, which had no 'development strategy' in a conventional sense. This was consistent with the de-emphasis on material prosperity that had become ingrained in Bhutanese culture, which received rather colourful expression in the royal proclamation that Bhutan would pursue the goal of Gross National Happiness $(\mathrm{GNH})$, as distinct from the pursuit of Gross National Product (GNP) that is embodied in conventional development strategies.

Quantitative measures of some of the economic and social conditions obtaining in this region in the first half of the 1960s are presented in Table A2. On comparing these figures among the countries within the region as well as between them and various regional groupings of developing countries, the following features may be highlighted. ${ }^{3}$

a) In terms of per capita income, the region was poorer than most developing regions in the world but not in comparison with the rest of Asia. Within the region, Sri Lanka was by far the most prosperous country and Nepal the poorest.

b) There was a negligible manufacturing base in Nepal and Bangladesh, with GDP shares of 3.3 per cent and 5.4 per cent, respectively. Pakistan and Sri Lanka were somewhat better in this regard but they, too, were well below the countries of East Asia and Latin America.

c) Bangladesh and Pakistan were the most populous countries of the region, accounting for some 85 per cent of its total population. Bhutan was by far the tiniest, with a population of about 200,000 .

d) With more than 400 people per square kilometre, Bangladesh had an exceptionally high population density. For comparison, South Asia as a whole (including India) had a density of 128, East Asia 59, and the other developing regions only around 10-12.

e) With a life expectancy of 59 years and 94 per cent enrolment at the primary level, Sri Lanka was way ahead of the rest of the region, as well as most other developing regions, in terms

\footnotetext{
${ }^{3}$ As far as economic indicators are concerned, Bhutan is excluded from these observations, since systematic economic data began to be collected in Bhutan only from around 1980, although some social and demographic indicators are available for the 1960s.
} 
of health and education. Within the region itself, Bhutan and Nepal lagged the furthest behind, with Pakistan and Bangladesh occupying a position somewhere in between.

\section{Structural transformation}

All the countries in the region have gone through significant structural changes over time, as one would expect in conjunction with economic growth. Table 1 shows how growth performance itself changed between the first half and second half of the 50-year period from 1965 to 2015. Growth accelerated between the two halves in three out of the five countries-namely, Bangladesh, Nepal, and Sri Lanka. The acceleration has been the sharpest in Bangladesh, where the growth rate doubled from 2.7 per cent per annum in the first half to 5.4 per cent in the second. In comparison, the acceleration in Nepal and Sri Lanka has been marginal. As for the two countries that have experienced growth deceleration, Bhutan's case is somewhat special because its growth rate in the 1980s (10.1 per cent) was a bit artificial, built as it was on a low base. The only genuine deceleration is observed in Pakistan, where the growth rate went down from 5.8 per cent in the first half to 4.1 per cent in the second.

Table 1: Growth of GDP: 1966-2015 (\% per annum)

\begin{tabular}{lcc|cc|cc}
\hline & \multicolumn{2}{c|}{$\begin{array}{c}\text { Per capita GDP } \\
\text { growth }\end{array}$} & \multicolumn{2}{c}{ GDP growth } & \multicolumn{2}{c}{ Population growth } \\
& $1961-90$ & $1991-2015$ & $1961-90$ & $1991-2015$ & $1961-90$ & $1991-2015$ \\
\hline Bangladesh & 0.1 & 3.6 & 2.7 & 5.4 & 2.6 & 1.7 \\
Bhutan & 7.1 & 5.0 & 10.1 & 6.6 & 3.0 & 1.6 \\
Nepal & 1.1 & 2.7 & 3.3 & 4.4 & 2.2 & 1.8 \\
Pakistan & 2.7 & 1.8 & 5.8 & 4.1 & 3.1 & 2.3 \\
Sri Lanka & 2.8 & 4.5 & 4.6 & 5.4 & 1.8 & 0.9 \\
India & 2.1 & 4.9 & 4.4 & 6.6 & 2.3 & 1.7 \\
\hline
\end{tabular}

Notes: (1) The initial figures for Bhutan relate to the decade 1981-90, since national income data are not available for Bhutan prior to 1980. (2) In this and subsequent tables we include Indian data, purely for a quick comparison, but without any comments in the text, because the Indian experience is not in the purview of this paper.

Source: World Bank's World Development Indicators (WDI) database.

The pattern of change in the growth of per capita income is very similar to that of the overall growth rate. However, differential success in reining in population growth have made a difference, especially in sharpening the contrast between Bangladesh and Pakistan. In Bangladesh, acceleration in GDP growth has been accompanied by a significant decline in population growth, which has resulted in a very sharp acceleration in per capita GDP growth-from a negligible 0.1 per cent in the first half of the period to a respectable 3.6 per cent in the second half. In contrast, Pakistan's growth deceleration has been accompanied by a relatively modest fall in population growth, resulting in a rather sharp deceleration in per capita GDP growth-from 2.7 per cent to just 1.8 per cent, half the rate enjoyed by Bangladesh.

The pattern of structural transformation that has followed from economic growth can be seen from Table 2, where changes in sectoral contribution to GDP are compared as between the first five years (1966-70) and the final five years (2011-15) of the 50-year period. As expected, the share of agriculture has declined sharply in all the countries and the share of industry increased. However, industry is a broad category that includes hydropower (e.g. in Bhutan and Nepal) and 
plantation (in Sri Lanka) as well as construction and manufacturing. Considering the narrower category of manufacturing alone, the extent of transformation in the sense of modernization of the economy has been relatively modest. This is true especially of Nepal and Bhutan, where the share of manufacturing remains well below 10 per cent. Even in the other three countries, the share is currently less than 20 per cent, whereas, for comparison, the share of manufacturing in the GDP of the East Asia and Pacific region during the same period has remained close to 30 per cent.

Table 2: Sectoral contribution to GDP: 1966-70 and 2011-15 (\%)

\begin{tabular}{lcccccc}
\hline & \multicolumn{2}{c}{ Agriculture } & \multicolumn{2}{c}{ Industry } & \multicolumn{2}{c}{ Manufacturing } \\
& $1966-70$ & $2011-15$ & $1966-70$ & $2011-15$ & $1966-70$ & $2011-15$ \\
\hline Bangladesh & 54.7 & 16.5 & 9.1 & 27.3 & 5.9 & 17.2 \\
Bhutan & $\mathrm{n} / \mathrm{a}$ & 17.3 & $\mathrm{n} / \mathrm{a}$ & 43.6 & $\mathrm{n} / \mathrm{a}$ & 8.8 \\
Nepal & 68.2 & 35.3 & 10.3 & 15.5 & 3.6 & 6.5 \\
Pakistan & 38.0 & 25.1 & 20.8 & 21.1 & 15.3 & 14.1 \\
Sri Lanka & 29.7 & 8.6 & 21.8 & 30.8 & 16.1 & 19.2 \\
India & 44.6 & 18.2 & 23.6 & 31.0 & 15.6 & 16.8 \\
\hline
\end{tabular}

Note: National income data are not available for Bhutan prior to 1980.

Source: World Bank's World Development Indicators (WDI) database.

The growth and structural transformation of the last 50 years have been underpinned by a considerable increase in the rate of capital formation and trade orientation (Table 3). Pakistan is a notable exception with regard to the rate of investment, which actually declined over the periodfrom 16.2 per cent at the beginning of the period to 14.9 per cent towards the end. This goes a long way towards explaining why Pakistan is unique in the region in facing a growth deceleration between the two halves of the period. As for trade orientation, Sri Lanka was by far the most tradeoriented country at the beginning of the period, thanks mainly to its reliance on the plantation sector. Over the years, Sri Lanka has increased its trade ratio slightly-from 46.7 per cent in the beginning to 51.1 per cent at the end. By the end of the period, Bhutan had turned into the most open economy of the region, with a trade ratio of over 100 per cent, which is a consequence of the country's overwhelming dependence on India for all its hydropower exports as well as most of its consumer goods imports.

Table 3: Investment and trade: 1966-70 and 2011-15 (\% of GDP)

\begin{tabular}{lcccc}
\hline & \multicolumn{2}{c}{ Investment rate } & \multicolumn{2}{c}{ Trade ratio } \\
& $1966-70$ & $2011-15$ & $1966-70$ & $2011-15$ \\
\hline Bangladesh & 11.5 & 28.3 & 21.1 & 45.7 \\
Bhutan & $\mathrm{n} / \mathrm{a}$ & 57.4 & $\mathrm{n} / \mathrm{a}$ & 101.0 \\
Nepal & 5.3 & 38.0 & 14.6 & 47.8 \\
Pakistan & 16.2 & 14.9 & 24.0 & 31.5 \\
Sri Lanka & 16.7 & 33.3 & 46.7 & 51.1 \\
India & 16.5 & 35.9 & 1.2 & 3.5 \\
\hline
\end{tabular}

Notes: (a) National income data are not available for Bhutan prior to 1980. (b) Trade ratio refers to the ratio of the sum of exports and imports to GDP.

Source: World Bank's World Development Indicators (WDI) database. 
There has also been a significant change in the region's dependence on foreign aid: all the countries are now much less dependent on foreign aid than they used to be (Table 4). In this sense, the region has become much more self-reliant. The most significant change in this regard has taken place in Sri Lanka and Bangladesh. During the last three decades, the flow of foreign aid has gone down in Sri Lanka from 8.4 per cent of GDP to less than 1 per cent, and in Bangladesh it has fallen from almost 6 per cent to 1.3 per cent. The flow of foreign aid to Nepal and Bhutanoriginating mostly from India, on which both countries continue to be highly dependent — remains high in absolute terms, but even there it has fallen somewhat as a percentage of GDP.

Table 4: Role of foreign aid: $1981-85$ and $2011-15(\%)$

\begin{tabular}{lcccc}
\hline & \multicolumn{2}{c}{ \% of GNI } & \multicolumn{2}{c}{ \% of investment } \\
& $1981-85$ & $2011-15$ & $1981-85$ & $2011-15$ \\
\hline Bangladesh & 5.9 & 1.3 & 35.8 & 5.1 \\
Bhutan & 11.7 & 7.7 & 24.1 & 12.6 \\
Nepal & 8.0 & 4.6 & 42.6 & 12.3 \\
Pakistan & 2.4 & 1.2 & 14.1 & 8.6 \\
Sri Lanka & 8.4 & 0.7 & 30.4 & 2.0 \\
India & 0.8 & 0.1 & 3.9 & 0.4 \\
\hline
\end{tabular}

Source: World Bank's World Development Indicators (WDI) database.

A final noteworthy feature of the structural change in the region is its heavy reliance on workers' remittances. In all the countries except Bhutan, the flow of remittances is high and has increased sharply over the years (Table 5). The magnitude of increase has been the most spectacular in Nepal, where remittances amounted to 27.5 per cent of GDP during 2011-15, making it an exceptionally remittance-dependent country by international standards, not just by the standards of the region.

Table 5: Role of remittances: 1981-85 and 2011-15 (\% of GDP)

\begin{tabular}{lcc}
\hline & $1981-85$ & $2011-15$ \\
\hline Bangladesh & 2.7 & 9.1 \\
Bhutan & na & 0.8 \\
Nepal & 1.3 & 27.5 \\
Pakistan & 8.5 & 6.5 \\
Sri Lanka & 5.4 & 8.6 \\
India & 1.2 & 3.5 \\
\hline
\end{tabular}

Note: Nepal's initial figures refer to the period 1993-96.

Source: World Bank's World Development Indicators (WDI) database.

The main features of growth and structural transformation of the region may be summarized as follows. First, all the countries except Pakistan have experienced a substantial growth acceleration in the period since around 1990. Second, the growth acceleration has been underpinned by rapid increases in the rates of savings and investment on the one hand and increasing trade openness on the other. Third, the rise in investment rates is especially remarkable in view of the fact that the region's dependence on foreign aid has fallen drastically. Higher rates of investment have been sustained partly by internal resource mobilization, and largely by a sharp rise in the flow of workers' remittances. Fourth, the structural transformation that has accompanied growth acceleration has been characterized by a sharp decline in the share of agriculture in national output, but without a 
correspondingly sharp increase in the share of manufacturing; it is services that have led the way. Finally, Pakistan has been an exception to the general pattern in the region; it has experienced neither the kind of growth acceleration nor the surge in investment that has been observed in the rest of the region.

The preceding summary makes it clear that the growth acceleration that has occurred since 1990 is what one would expect from the basic tenets of development theory. Rises in investment rates and in the degree of trade openness are widely recognized to be among the major factors (though by no means the only ones) that propel economic growth, both on their own and through their interaction with each other. Both these factors have improved significantly in the second half of the period under consideration, making the growth acceleration possible. At the same time, a comparison of these factors with those of East Asia helps to explain why the region is lagging behind. Most of the countries of the region have failed to reach the levels that East Asia has achieved-in terms of both investment rates (43 per cent in 2011-15) and trade openness (56 per cent during 2011-15).

\section{Growth reversal of the 1970s}

Before attempting to unravel the forces behind the patterns of growth and structural transformation in South Asia, it is necessary to note that, soon after Myrdal wrote Asian Drama in the mid-1960s, growth prospects actually dimmed in South Asia (including India) before they began to improve. For most of the 1970s, the region faced a reversal in the growth momentum that had been generated in the preceding decades. For this reason, this decade has been described as the 'dismal decade' of South Asia (Osmani 2009). ${ }^{4}$

As can be seen from Table 6, the rate of growth declined in the 1970s from the rates achieved in 1966-70 in all countries for which data are available. ${ }^{5}$ It was only in the 1980s, and in some cases in the 1990s, that signs of transition to a higher growth path began to emerge. The setback that happened in the 1970s, and the struggles the countries had to go through to recover from this setback, explain in no small measure why South Asia has lagged behind East and Southeast Asia in the last 50 years in spite of starting from a roughly comparable position. In order to understand the overall growth performance of the region, it is therefore necessary to understand why the reversal happened in the first instance and how the countries attempted to climb out of it in the subsequent decades.

\footnotetext{
${ }^{4}$ The 1970s was of course a bad time for the global economy generally, owing mainly to the oil price shock and the policy responses to it. But the situation was especially bad for South Asia for reasons that were specific to the region, which is what justifies describing the 1970s as the dismal decade for South Asia, much more so than for any other developing region. For more on this, see Osmani (2009).

${ }^{5}$ The precise period during which the growth reversal happened varied between countries, and the record of growth during those periods is a lot worse than the average for the entire decade of the 1970s shown in the table. For details of these variations, see Osmani (2009).
} 
Table 6: Growth reversal and the subsequent transition (growth of GDP per annum; \%)

\begin{tabular}{lccc}
\hline & $1966-70$ & $1971-80$ & $1981-2015$ \\
\hline Bangladesh & 3.4 & 1.0 & 5.0 \\
Bhutan & na & na & 7.6 \\
Nepal & 2.6 & 2.1 & 4.5 \\
Pakistan & 7.1 & 4.7 & 4.7 \\
Sri Lanka & 5.8 & 4.4 & 5.1 \\
India & 4.6 & 3.1 & 6.3 \\
\hline
\end{tabular}

Note: National income data are not available for Bhutan prior to 1980.

Source: World Bank's World Development Indicators (WDI) database.

In explaining the growth reversal of the 1970s in South Asia (including India), it is common to attribute a central role to the alleged inefficiencies of a restrictive trade and industrial policy regime-in particular, of the import substitution strategy of development that was pursued throughout the region in the 1950s and 1960s. ${ }^{6}$ It is of course acknowledged that South Asia was not unique in pursuing the import substitution strategy and that East Asia was also pursuing a similar strategy around the same time and still achieved much bigger success in subsequent decades. The argument is rather that South Asia persisted with this strategy for far too long and implemented it much more vigorously than East Asia, thus suffering much more from the inefficiencies induced by the strategy. While this argument may have some validity in explaining a part of South Asia's growth shortfall relative to East Asia over the long term, it is a mistake to single out the cumulative effect of import substitution as the primary reason for the growth debacle of the 1970s. A number of conjunctural factors combined with a range of policy failures to cause that debacle, and the policy failures that occurred went far beyond mere persistence with import substitution.?

The overwhelming importance of conjunctural factors is obvious in Bangladesh, which emerged as an independent nation in December 1971 after a prolonged war of liberation. Its economic infrastructure was so badly damaged by the ravages of war that a prolonged decline in production became inevitable, irrespective of the policy framework adopted by the government. The problem was compounded by the disappearance of almost the entire entrepreneurial class. Most of the modern industries set up in the Pakistan period were owned and operated either by the state or by West Pakistani entrepreneurs or other non-Bengali entrepreneurs who had migrated from India at the time of the partition of British India in $1947 .{ }^{8}$ Almost all the non-local entrepreneurs, along with a large pool of skilled workers belonging to the non-Bengali migrant class, left Bangladesh for Pakistan after 1971, leaving behind a huge vacuum in entrepreneurial ability and industrial skill. In the process, a large number of modern industries became ownerless, leaving the government with a choice between nationalizing them and auctioning them off to private entrepreneurs. In the event, the first option was chosen, partly because of the absence of a strong indigenous entrepreneurial class, and partly in deference to the socialist ideal of the leadership of the newly

\footnotetext{
${ }^{6}$ The exception was Bhutan, which did not pursue any kind of industrialization strategy to speak of until the 1980s.

${ }^{7}$ For an elaborate development of this argument for the whole of the South Asia region, including India, see Osmani (2009).

${ }^{8}$ Before 1971, only 18 per cent of fixed assets in large-scale manufacturing were owned by indigenous Bangladeshi entrepreneurs, the rest being allocated as follows: state sector 34 per cent, West Pakistani and other non-Bengali entrepreneurs 47 per cent, and foreigners 1 per cent (Sobhan and Ahmad 1980).
} 
independent country. At the same time, unrelenting balance of payments crises forced the government to adopt various restrictive measures including high tariffs, quantitative restrictions on imports, and import licensing, resulting in high and variable incentives for import substitution. It is thus fair to say that the restrictive trade and industrial policies of this decade were more a consequence than a cause of the economic meltdown, which was primarily due to exogenous factors.

In Pakistan, too, the poor performance of the economy in the dismal decade must be attributed mainly to factors other than the trade regime. Never before had the Pakistani economy been buffeted by so many successive shocks. To begin with, half of the country's export market suddenly disappeared when East Pakistan became Bangladesh in December 1971. The disruptive effect of this loss of export market was aggravated by the phenomenal increase in the country's import bill following the oil price of shock of 1973. At the same time, agricultural output was severely disrupted by a series of floods and pest attacks.

The effects of these shocks were compounded by the radical programme of economic reform adopted by Prime Minister Zulfiqar Ali Bhutto. He came to power in December 1971 with an avowedly socialist agenda of land reform and nationalization of industries. In the event, the implementation of land reform fell far short of its aim, but the disruption caused by government rhetoric and the piecemeal nature of implementation created enough uncertainty to dampen the growth of investment in agriculture.

Especially damaging was the nationalization programme. In a throwback to the Indian strategy of the 1950s of vesting control of the 'commanding heights of the economy' in the state, Bhutto's manifesto declared: 'The means of production that are the generators of industrial advance or on which depend other industries must not be allowed to be vested in private hands' (Bhutto 1968). Accordingly, a number of large firms belonging to the basic industries sector as well as public utilities were nationalized in January 1972. This action was soon followed by the nationalization of the financial sector, much as in India under Indira Gandhi at around the same time. Bhutto's original agenda did not include the nationalization of consumer goods industries or private trade; indeed, after the initial round of nationalization Bhutto promised not to extend it further. But he soon broke his promise, and went about nationalizing a number of trading and manufacturing activities connected with cotton, rice, vegetable oil, petroleum, and shipping.

All this had a severely dampening effect on private investment-the driving force behind Pakistan's growth in the preceding decades. ${ }^{9}$ By 1974/75, total investment in large-scale manufacturing had dwindled to just one-third of the level of 1969/70. The precipitous decline of manufacturing in the dismal decade was but the inevitable consequence of this slump in investment. It is thus reasonable to argue that the slump of the 1970s owed much more to the joint squeeze delivered by exogenous shocks and Bhutto's anti-private-enterprise policies than to the inefficiencies of import-substituting industrialization in the preceding decades. ${ }^{10}$

\footnotetext{
${ }^{9}$ The broken promises proved especially damaging as private entrepreneurs lost their trust in the government. 'His assurance of no further nationalization until the elections of 1977 no longer seemed meaningful and the little confidence that the businessmen had developed in the regime was now completely gone.' (Burki 1980: 118).

${ }^{10}$ There is, however, a different and more subtle sense in which the preceding import substitution regime can be held responsible to some extent. The real culprit here is not the alleged inefficiencies but inequities that were generated by the preceding regime. By the late 1960s, the perception of a very unequal political and economic regime had become widespread among the population and formed the basis of a popular unrest which eventually toppled the incumbent military regime. Bhutto, being in the vanguard of political agitation in West Pakistan, clearly understood the economic basis of mass resentment against the status quo, and gained popularity by promising to destroy the structures of
} 
In the case of Sri Lanka, two different aspects of the policy regime have generally been blamed for the growth debacle of the 1970s. One of them is the common theme of excessive reliance on import-substituting industrialization. The other is unique to Sri Lanka-viz. its policy of maintaining persistently high levels of welfare expenditure until the 1980s. Several commentators have argued that whatever contributions these welfare expenditures might have made towards human development in Sri Lanka, they entailed a trade-off with economic growth, and that the crisis of the 1970s was but an inevitable consequence of this anti-growth bias of the welfarist regime.

Neither of these lines of argument stands up to careful empirical scrutiny. ${ }^{11}$ As in other countries of the region, the proximate cause of the crisis was a series of shocks that buffeted the economy soon after a left-wing coalition government came to power in 1970. The major shock came from a precipitous decline in the external terms of trade, owing partly to a decline in the price of Sri Lanka's major export crops and partly to the oil price shock of $1973 .{ }^{12}$ The problem was compounded by several domestic shocks — in both plantation and traditional agriculture-which reduced export earnings on the one hand and raised the need for food imports on the other. At the same time, the country's ability to finance imports was further constrained as loans from the World Bank were withheld because the new left-wing government was unwilling to countenance cuts in consumer subsidies, which the World Bank was insisting on. All these factors conspired together to make it impossible for Sri Lanka to maintain the level of imports of essential inputs that the country's manufacturing sector had become accustomed to. Primarily as a consequence of this supply constraint, the manufacturing sector failed to utilize almost half of its capacity up to the mid-1970s, and industrial stagnation ensued.

As in the case of Pakistan, policy mistakes did aggravate the crisis, but the real problem did not lie either in the pursuit of import substitution or in commitment to the welfare state. The problem lay in the creation of an overbearing state-in particular, in excessive reliance on the public sector as the principal vehicle for driving growth. The Ten-Year Plan for 1959-68, which launched Sri Lanka on the path to industrialization, was deeply influenced by the Nehru-Mahalanobis strategy prevailing in India at the time, but Sri Lanka went far ahead of India in its reliance on the public sector. In the event, the Ten-Year Plan never became fully operational, and prior to 1970 the scope of the public sector remained smaller than was originally envisaged. However, soon after the leftwing collation, led by Srimavo Bandaranaike, came to power in 1970, the overbearing state spread its tentacles to all aspects of the economy-industry, agriculture, trade, and key service sectors. Thus, the economy that evolved in the 1970s was characterized by complete dominance of the state, which induced widespread rigidities and inefficiency. ${ }^{13}$

It is thus evident that the genesis of the 'dismal decade' in South Asia was a complex phenomenon going far beyond trade strategy. In all the countries, a series of supply shocks played a major role in precipitating the crisis. Erroneous policies were certainly responsible for aggravating the crisis, but the real culpability lay not so much with the policy of import substitution as with the excess of state intervention engulfing every sphere of the economy.

inequality if voted to power. This was the political economy root of Bhutto's socialist agenda that came to wreak havoc in the 1970s.

${ }^{11}$ For a detailed rebuttal of both these lines of argument, see Osmani (1994).

${ }^{12}$ The terms of trade declined by a massive 50 per cent between 1970 and 1975 .

${ }^{13}$ For evidence and further elaboration of these arguments see, among others, Athukorala and Jayasuria (1994), Athukorala and Rajapathirana (2000), and Osmani (2009). 


\section{$5 \quad$ Attempted transition to a higher growth path}

The dismal decade of South Asia came to an end towards the end of the 1970s. The first country to try to break out of the shackles was Sri Lanka, around 1977/78, followed by Pakistan and then Bangladesh and Nepal. The transition was marked by a decisive shift in policy regime in each of the countries. The new regimes had many common features across the countries, although the vigour and consistency with which they were implemented varied from country to country. On the whole, the new regimes entailed a significant softening of the administrative grip on the economy, allowing a freer play of market forces both within the domestic sphere and in the conduct of external economic relations. ${ }^{14}$

\subsection{The initial reforms}

In Sri Lanka, the reform process started in 1977, when the right-wing United National Party (UNP) led by J.R. Jayawardene returned to power with massive popular support. With the help of Bretton Woods institutions, the new government embarked upon an ambitious reform programme. The list of reforms included the replacement of quantitative restrictions by tariffs on most import items, across-the-board reduction in tariff rates, hefty devaluation of the currency against the dollar, removal of exchange control for current account transactions, withdrawal of state monopoly over import trade and the distribution of essential commodities, elimination of price controls, rationalization of state-owned enterprises, and special incentives to exporters of manufactures. A radical change also occurred in social welfare policy with the abolition of direct consumer subsidies. The rice ration system was replaced by a system of food stamps targeted at low-income groups.

In Pakistan, on his assumption of power in 1977, General Ziaul Haq initiated reforms with the avowed aims of reversing the statist strategy of the previous regime and restoring business confidence within the private sector. To this end, steps were taken to denationalize a few of the industries, to soften the grip of the investment licensing system, and to encourage the private sector to enter areas not reserved for the public sector.

In Bangladesh, a major thrust towards liberalization came with the launching of the New Industrial Policy (NIP) in 1982, which initiated a process of denationalization and stimulation of private enterprise. By 1985, only about 40 per cent of industrial assets remained in the public sector, as compared with 90 per cent in the early 1970s. Nepal moved much more slowly than the others, in the early 1980s, relying mainly on a depreciation of the currency aimed at boosting exports.

These early reforms had very little impact on the real economy, however. There was indeed an economic upturn at that time, but in all cases it was engineered by an unprecedented expansion of demand that brought about higher growth through fuller utilization of the excess capacity that had emerged in the 1970s.

In Sri Lanka, the expansion of domestic demand came from two main sources. First, the government embarked upon an investment programme of unprecedented magnitude with two major components-one involving large-scale irrigation and land development under the Mahaweli Development Project and the other involving an ambitious housing programme. Second, the investment effort was supported by an exceptionally generous flow of foreign

\footnotetext{
${ }^{14}$ The following discussion leaves out Bhutan, whose story has some unique features. That story is told briefly in a separate sub-section at the end of this section.
} 
assistance from Western donors who were keen to ensure the success of Sri Lanka's pioneering effort at economic liberalization. In the process, the budget deficit soared from about 8 per cent of GDP during 1970-77 to 19 per cent during 1978-83.

In Pakistan and Nepal, too, the initial boost to domestic demand came from expansionary fiscal policy. The fiscal deficit increased from an average of 5.3 per cent of GDP in the 1970s to 7.1 per cent in the 1980s in Pakistan ${ }^{15}$, and from 3.1 per cent to 6.7 per cent in Nepal ${ }^{16}$. Bangladesh was slightly different in the sense that credit policy was the principal vehicle for demand expansion. In order to ensure the success of the privatization programme that stemmed from the NIP, launched in 1982, the potential buyers of state-owned enterprises were lured with cheap credit from the nationalized banking system, resulting in a credit explosion.

It is arguable that some degree of demand expansion made sense in the 1980s for all these countries, as it helped exploit the slack that had been generated by the crisis of the 1970s. The problem, however, was that, in all cases, the expansion of demand was carried to the extreme, thereby storing up macroeconomic imbalances for the future, which led invariably to growth retardation, principally through fiscal squeeze and partly through appreciation of the real exchange rate that resulted from higher inflation.

\subsection{More broad-based reforms}

Deep-rooted structural problems eventually began to outweigh the stimulus of demand expansion, resulting in the slowdown of growth. The emerging crisis prompted a series of structural adjustment programmes starting from the second half of the 1980s, which, apart from trying to stabilize demand, also aimed at implementing far-reaching market-oriented reforms in both domestic and external sectors.

While the nature of reform was very similar in all the countries, the results were very different because of the different ways in which the political economy of the countries evolved in the subsequent period. The biggest problems were faced by Pakistan and Nepal; Sri Lanka somehow muddled through, and Bangladesh was the only country that was able to enjoy sustained benefits from the reforms.

In Pakistan, the decade of the 1990s was marked by an intense power struggle among the major political parties on the one hand and the military-bureaucratic nexus on the other, which resulted in the dismissal of four elected governments, culminating in yet another military coup in 1999. The fallout of this turmoil was a severe deterioration in economic performance-so much so that during the five-year period 1997-2002, GDP growth plummeted to an average of barely 3 per cent, which was even lower than had been achieved in the 'dismal decade'.

There was a turnaround in the Pakistan economy after 2002/03, when General Parvez Musharraf was in power, with GDP growing at the remarkably high rate of 6.2 per cent per annum during 2002-07. As in the early 1980s, this growth spurt was brought about not so much by structural reforms as by expansion of aggregate demand, supported by expansionary fiscal policy, a huge

\footnotetext{
${ }^{15}$ Three other factors also contributed: depreciation of the currency, a surge in workers' remittances, and a large inflow of Western aid, which poured in mainly to help Pakistan train and arm the Afghan mujahideen, who were fighting against the Soviet invasion of Afghanistan. Average annual foreign aid committed to Pakistan increased from US $\$ 1.45$ billion during 1970-78 to as much as US\$2.29 billion during 1983-88 (Ahmad and Laporte 1989).

${ }^{16}$ At the same time, the money supply also increased rapidly, the supply of broad money rising from 16.2 per cent of GDP to 27.2 per cent. For more on the reforms in Nepal, see Osmani and Bajracharya (2008) and Mahat (2018).
} 
inflow of foreign aid as a reward for the country emerging as a major ally of the United States in the global war on terrorism, and a spectacular increase in the inflow of workers' remittances (Hasan 2008). But, like all other booms in the history of Pakistan, this one, too, was short-lived-it ended with the onset of the global financial crisis in 2007/08, when Pakistan entered into the longest downturn in its history, from which it has barely begun to emerge.

The history of growth in Pakistan is thus one of a series of booms and busts. Political uncertainty has played a huge part in causing these economic cycles, which in turn has had a deleterious longterm effect on the economy by causing a secular stagnation of investment. Since 1980, Pakistan's investment ratio has been the lowest in the region; not surprisingly, its growth performance has also been the weakest.

In Nepal too, the potential benefits of reforms were swamped by the fallout from political turmoil. For a while, the reforms instituted in the early 1990s did seem to yield some tangible results. The share of exports in GDP almost doubled from 5 per cent in the 1980s to close to 10 per cent in the 1990s, and GDP grew at the moderate rate of 5 per cent in the 1990s. While this was not very different from the rate of growth achieved in the 1980s, it was based on more sustainable economic foundations.

In the event, however, the growth rate actually slumped after 2000, averaging only 2.7 per cent during 2000-05; and this slump was attributable primarily to the political turmoil emanating from an especially severe Maoist insurgency and a protracted power struggle between politicians and the royalty. Despite the economic progress made in the previous period, Nepal's development was fragile and fraught with deficiencies. Most importantly, not all regions or groups were able to participate equally in growth and human development. In particular, the Western and Far Western regions (about 22 per cent of the population), Dalits (the lowest caste or 'untouchables'), and indigenous nationalities (Adivasi Janajatis) (about 46 per cent of the population) lagged behind badly.

Growing inequality sowed the seeds of a Maoist insurgency, which started in 1996 and intensified after 2001, leading to a serious deterioration in security and disruption in development and governance in large parts of Nepal. Democratic institutions were progressively suspended, and in February 2005, King Gyanendra assumed direct rule. The turmoil resulted in large war-related costs and slow progress in reforms, leading to a marked slowdown in growth. Furthermore, an increasingly competitive global environment, brought about by the phasing-out of the quota that was guaranteed under the Multi-Fiber Agreement (MFA), resulted in a steady loss in the market share of Nepali exports.

The next period, from 2007 to date, can be classified as the post-conflict period, in which the main focus was on a new political compact, which overshadowed economic issues. The political compact around the new interim Constitution endorsed the devolution of power, social and political inclusion, democratic elections, and political accountability. However, the peace dividend that many had anticipated failed to materialize, and the economy sputtered forward at an average growth rate of 4.7 per cent during this period. The sharp increase in investment that was expected did not materialize, while Nepal's investment climate may have been worsened by the prolonged period of political transition and uncertainty. ${ }^{17}$

\footnotetext{
${ }^{17}$ The opportunities and challenges emerging in the post-conflict era are insightfully analysed in Pant et al. (2017) and World Bank (2017).
} 
Sri Lanka's post-reform growth trajectory also went through a few ups and downs, but on average the economy kept growing at the moderate rate of around 5 per cent during 1985-2005. Several structural bottlenecks are responsible for Sri Lanka's failure to move on to an even higher growth path after the initial recovery.

Some of these bottlenecks are legacies of the profligate macroeconomic policy the country had pursued after $1977 .{ }^{18}$ First, the country failed to accelerate the pace of investment due to fiscal constraints. The mounting budget deficits of the 1980s led to such a high level of public debt that interest payments on past debts became a major drain on the budget. At the same time, defence expenditure rose dramatically due to the civil war-from just 2 per cent of government expenditure during 1950-80 to 16 per cent in the 1990s. Second, by keeping the inflation rate high, the legacy of fiscal profligacy led to persistent appreciation of the real exchange rate and erosion of export competitiveness. Third, rising public debt encouraged the government to keep the interest rate artificially low so as to reduce its debt servicing burden. In the face of high inflation, however, this resulted in a negative real interest rate, to the detriment of savings.

By the mid-2000s, a widespread disenchantment had set in among Sri Lankans with the unfulfilled promises of the liberalized policy regime of the preceding quarter-century. A decisive shift in policy orientation came when the coalition government of the United People's Freedom Alliance (UPFA) came to power in 2004, and it was intensified when Mahinda Rajapakse, the candidate of the leftleaning Sri Lanka Freedom Party (SLFP), won the Presidential election of November 2005. The new government's development ideology and policy directions marked a deliberate attempt to move away from many of the fundamental tenets of the preceding regime. ${ }^{19}$

The government placed special emphasis on social development, distributive policies, extensive government intervention, and 'domestic' economic activities of the rural populations. In the process of pursuing this agenda, the government reverted to the inward-looking protectionist development policy of the past. The introduction of para-tariffs effectively doubled the protection rates, making the new import regime one of the most complex and protectionist in the world. Restrictive trade policies created a strong anti-export bias, which was reflected in a dramatic decline in the trade-to-GDP ratio-from 89 per cent in 2000 to 48 per cent in 2016.

Overall growth performance did not, however, suffer in the short run. In addition to policy actions that boosted domestic demand, the end of the decade-long civil war in the North in 2009 provided a significant boost to the economy. The ensuing peace dividend, in combination with the domesticdemand-oriented policy, has enabled the country to maintain a steady enough growth over a prolonged period. There is, however, no sign of the growth acceleration that many expected the peace dividend to yield.

In Bangladesh, the eventual transition to a higher growth path coincided with its democratic transition at the outset of the 1990s. Improved performance in both agriculture and manufacturing contributed to the acceleration of growth. A combination of policy interventions and favourable external conditions helped to bring about this transformation. ${ }^{20}$

In agriculture, a major boost came from the liberalization of markets for agricultural inputs, especially the elimination of non-tariff barriers to the importation of cheap irrigation equipment

\footnotetext{
${ }^{18}$ Kelegama (2008) provides a perceptive analysis of the legacy of the fiscal profligacy of the 1980s.

${ }^{19}$ See World Bank (2016b) for a detailed discussion of this policy shift and its implications.

${ }^{20}$ For a fuller analysis of the growth acceleration in Bangladesh since the 1990s, see Osmani et al. (2006).
} 
with effect from 1988. Liberalized imports led to a drastic reduction in the price of shallow tube well, which, together with the relaxation of siting restrictions, resulted in a rapid increase in the use of tube wells. The expansion of irrigation coverage brought in its wake an equally impressive increase in the use of fertilizer, and together they accelerated agricultural growth.

Growth in manufacturing was led by the export-oriented garments sector, which benefitted from a combination of policy reform and conjunctural factors. On the policy front, trade liberalization played a key role. Between the late 1980s and early 1990s, Bangladesh embarked upon one of the most remarkable episodes of trade liberalization in the contemporary world, slashing tariff rates much faster than most other developing countries in Asia and elsewhere. ${ }^{21}$ Reduced protection, coupled with a variety of direct incentives offered to export-oriented firms, resulted in a substantial reduction in anti-export bias within the existing incentive structure. To a significant extent, export growth was also helped by external factors such as the MFA, which ensured easy access of Bangladeshi garments to the Western markets.

A couple of other factors also helped-namely, stronger mobilization of domestic resources and increased flow of workers' remittances. All these have enabled Bangladesh to maintain a steady acceleration in GDP growth since around 1990. From an average of 3.8 per cent in the 1980s, the growth rate has accelerated steadily, reaching an average of 6.3 per cent during 2010-15. Such a sustained acceleration in growth over a quarter of a century makes Bangladesh an exceptional performer in the region - in sharp contrast to Pakistan, Sri Lanka, and Nepal, all of which have struggled to sustain growth, let alone accelerate it, during the same period.

Continuity in the practice of democratic politics — which sets Bangladesh apart from Pakistan, Sri Lanka, and Nepal- has clearly contributed to making Bangladesh's recent performance stand out in the region. Seriously flawed as it has been, the practice of virtually uninterrupted democracy has created a relatively stable political environment, which has enabled the country to realize the potential benefits of economic reform and bulging remittances better than the rest of the region. ${ }^{22}$

Yet another distinctive feature of Bangladesh is the highly influential role played by the NGO community in softening some of the constraints to growth and development. By providing affordable credit to the vast majority of rural poor (covering by now over 60 per cent of the entire rural population), the microfinance institutions (led by the Grameen Bank) have softened the binding credit constraint that poor producers used to face ${ }^{23}$; through various grassroots programmes of women's empowerment (including microcredit), the NGO community has strengthened one of the major segments of the labour force; and through innovative initiatives for providing informal education and healthcare to the poor, many NGOs (led by BRAC, the largest NGO in the world) have helped improve the level of human capital in the parts of the society where it was lagging the most. ${ }^{24}$

\footnotetext{
${ }^{21}$ The unweighted protection rate came down from 73 per cent in 1991/92 to 28 per cent in 1995/96 (Mahmud 2004).

${ }^{22}$ Most observers of Bangladesh are convinced that, but for a fractured democracy and corruption-ridden governance, Bangladesh's performance would have been better still.

${ }^{23}$ According to one estimate, based on a CGE modelling exercise, in the absence of microcredit the GDP of Bangladesh would have been around 9-12 per cent lower than it was in 2012/13 and rural GDP would have been around 12-16 per cent lower, depending on the assumptions made (Raihan et al. 2017).

${ }^{24}$ In the process of undertaking the activities mentioned above, the NGO community has also made a significant contribution towards poverty reduction and human development, as noted in Section 6 below.
} 


\subsection{The story of Bhutan}

The story of Bhutan is rather different from that of the other countries in the region; it does not fit the pattern described so far, if only because the modernization of the Bhutanese economy is a much more recent phenomenon. Indeed, systematic and consistent national accounts data are available only from the 1980s onwards. Since then, GDP has grown at an average rate of almost 8 per cent. To a large extent, such a high growth rate reflects the very small base from which the growth process started. Furthermore, Bhutan has not been able to translate its high rate of growth into fundamental structural changes of the economy. Its growth has been underpinned mainly by the export of hydropower to India and activities related to hydropower, but the resulting growth has yet to lay the foundations of a modern industrial economy.

Ever since the mid-1980s, the economic growth of Bhutan has been inextricably linked to the development of hydropower. Apart from earning valuable export revenue, hydropower has contributed to GDP growth indirectly by boosting the construction sector through both backward and forward linkages and by facilitating the growth of power-intensive industries. The combined contribution of the energy sector itself, and of energy-related activities such as construction and power-intensive industries, has enabled Bhutan to sustain a remarkably high growth rate of around 8 per cent over a period of three decades, despite slow growth in agriculture.

Hydropower also makes an overwhelming contribution to the public exchequer, through both tax and non-tax revenue. Most of the government revenue earned from the sale of hydropower has been used to maintain high levels of social expenditure and to fund infrastructural development. At the same time, most of the earnings from electricity exports have been used to import consumer goods, including essential foodstuffs, from India. Without these imports, the social expenditure (as well as construction and other activities) spurred by hydropower development would have faced serious problems due to the wage-goods constraint. The softening of the wage-goods constraint has been one of the principal pathways through which hydropower has contributed to sustaining the growth process in Bhutan. ${ }^{25}$

The Government of Bhutan is keenly aware that, for a small country like Bhutan, international trade is essential in order to compensate for the limited availability of domestic resources as well as to overcome the limitations of a small local market. The most important trade policy instrument employed by Bhutan is the bilateral Free Trade Agreement with India. Since India accounts for about 95 per cent of Bhutan's export trade and over 80 per cent of its import trade, this agreement ensures that Bhutan follows by and large an open economy policy. Bhutan also has a preferential trade agreement (PTA) with Bangladesh, which is its second largest export market.

For the past three and a half decades, the development strategy of Bhutan has been underpinned by an overarching philosophy of human wellbeing. The last King of Bhutan enunciated this philosophy under the rubric of the Gross National Happiness (GNH) approach to development. By deliberately juxtaposing itself against the traditional preoccupation with the Gross National Product (GNP), this philosophy explicitly rejects the purely materialistic approach to development and calls for a holistic approach to development, embracing material, environmental, cultural, and spiritual goals.

For operational purposes, the GNH approach has been defined in terms of four pillars, viz. (1) equitable development, ensuring equity between individuals as well as regions, (2) environmental sustainability, (3) cultural and spiritual upliftment, and (4) good governance. Although there exists

\footnotetext{
${ }^{25}$ For further development of these arguments, see Osmani et al. $(2005,2008)$.
} 
some uncertainty as to how exactly to translate these principles into actual policy-making, the government of Bhutan continues to make serious attempts to ensure that its development strategy conforms to these principles as closely as possible. ${ }^{26}$

The choices made by the government in pursuit of these goals invariably entailed trade-offs with demands for material progress. So far, the government has managed these trade-offs without much sacrifice of material welfare — as evidenced by the sustained high rate of growth — but they remain a concern for the future. ${ }^{27}$

\section{$6 \quad$ Poverty reduction and human development}

The economic transformation of South Asia is reflected not only in rising per capita income but also in sharply falling poverty rates and all-round human development. As measured by the international poverty line, the extent of poverty was in the range of 44-62 per cent in the early 1990s-except in Sri Lanka, where it was less than 10 per cent. Since then, it has fallen drastically everywhere in recent years - to 15 per cent in Nepal, 13 per cent in Bangladesh, 6 per cent in Pakistan, and only about 2 per cent in Bhutan and Sri Lanka (see Figure 1). ${ }^{28}$

Long-term economic growth, and the accompanying structural transformation in occupation patterns, has played a major role in achieving this remarkable reduction in poverty across the region by opening up opportunities for gainful employment for increasing numbers of people. ${ }^{29}$ But other country-specific factors have also contributed. In Bangladesh, a major contribution has come from the microfinance revolution, which has reached nearly two-thirds of the rural population. By providing affordable credit to poor self-employed people, microfinance has enabled a significant number of them to climb out of poverty by seizing the opportunities opened up by the growth process. ${ }^{30}$ In Sri Lanka, the egalitarian policies pursued by the government since the middle of the 2000s has helped to render the growth process distinctly pro-poor. In Nepal and Pakistan, the huge amount of remittances sent by overseas migrant workers has been a major driver of poverty reduction. In Bhutan, the egalitarian philosophy underlying the GNH approach has helped to translate the riches of hydropower into higher living standards for the general population.

Impressive gains have been made in other dimensions of human development as well. Sri Lanka is well known for its stellar achievements in various dimensions of human development from the earliest stage of its development. In the 1960s and 1970s, when most developing countries were

\footnotetext{
${ }^{26}$ For an attempt to operationalize the concept of GNH in terms of practical policy-making, see, among others, Royal Government of Bhutan (1999).

${ }^{27}$ Some of the policy choices are analysed in ADB (2013) and World Bank (2014).

${ }^{28} \mathrm{I}$ have used the international poverty line for the sake of comparability across countries. Estimates of poverty based on national poverty lines tend to be somewhat higher; the time path is also not identical, but long-term trends are roughly similar to those based on the international poverty line.

${ }^{29}$ For a detailed analysis of the processes of poverty reduction in the region, see, among others, Osmani (2017), Osmani et al. (2006), Sen and Ali (2017), and World Bank (2013) on Bangladesh; ADB (2014) and NSB (2014) on Bhutan; Uematsu et al. (2016) and World Bank (2016a) on Nepal; Lopez-Calix et al. (2014) on Pakistan; and Gunatilaka et al. (2009) and World Bank (2015b, 2016b) on Sri Lanka.

${ }^{30}$ A recent, carefully conducted econometric exercise has estimated that, in the absence of microfinance, rural poverty would have been 46 per cent in 2010 instead of 33 per cent, the actual poverty rate. In other words, microfinance has helped make rural poverty 28.5 per cent lower than it would otherwise have been (Mahmud and Osmani 2016: chapter 7).
} 
almost obsessively preoccupied with growth, Sri Lanka set up an elaborate welfare state structure, quite atypical of countries at comparable levels of income. As a consequence, the health and educational outcomes of the people of Sri Lanka surged ahead of the levels achieved not just in South Asia but in most other developing countries, and even some developed countries of the world. In the process, Sri Lanka became a role model for the human development paradigm. ${ }^{31}$

Figure 1: Trend headcount index of poverty in South Asia (\% of population below the poverty line: US\$1.90 at 2011 PPP)

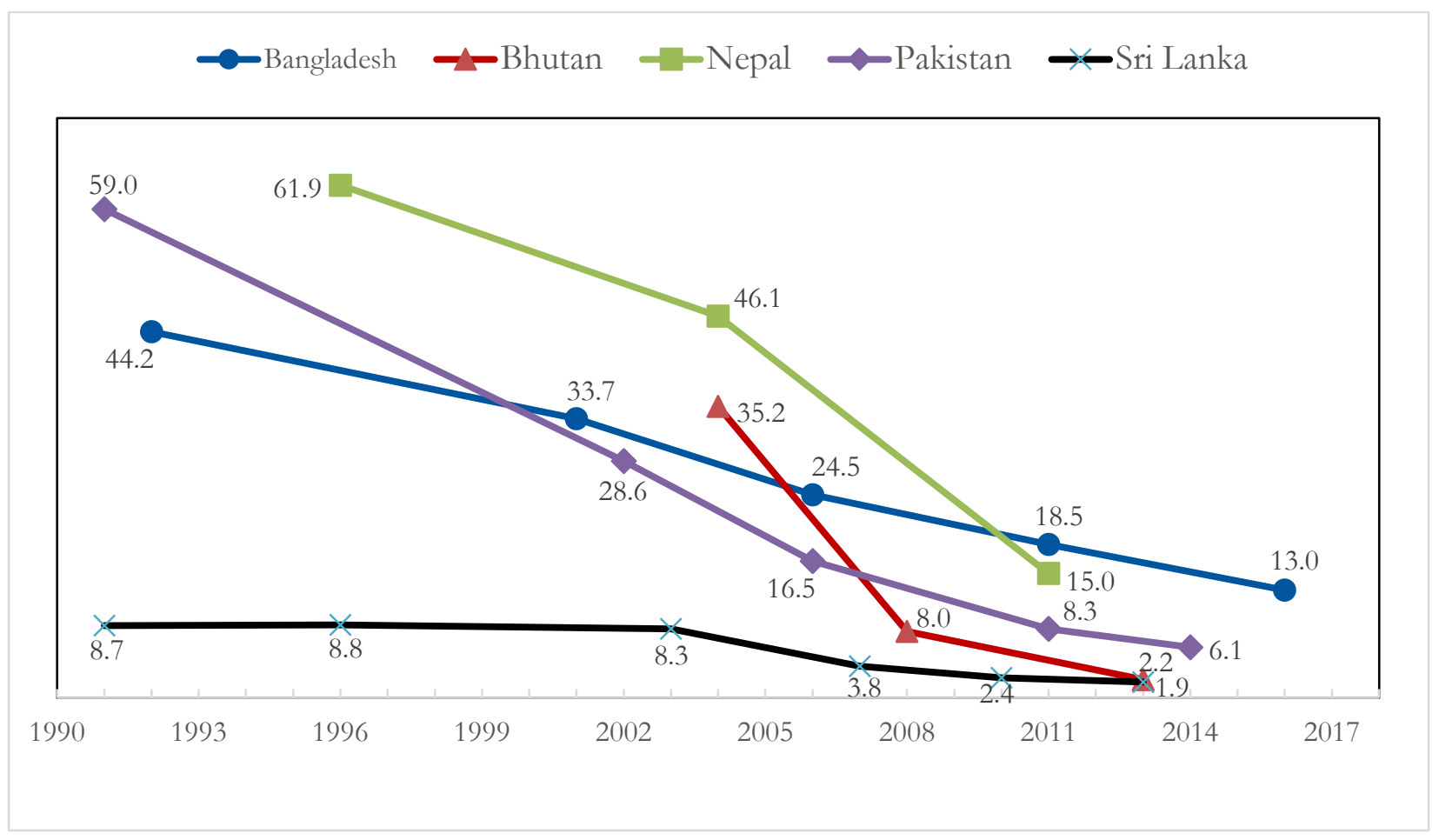

Source: World Bank's World Development Indicators (WDI) database for all figures except the figure for Bangladesh in 2016, which is the author's own estimate based on unit records of the Household Income and Expenditure Survey 2016.

Since the early 1990s, other countries in the region have also made impressive progress, without, however, quite achieving the levels of human development obtaining in Sri Lanka. The record of progress as measured by indicators such as life expectancy, infant mortality, and primary schooling has already been noted (in Section 2). The extent of progress made in nutritional status is depicted in Figure 2. It shows the trend of stunting (low height for age) among children under five years of age, which is usually taken as a general indicator of long-term nutritional stress among the population.

\footnotetext{
${ }^{31}$ Some commentators have argued that the contribution of welfare expenditure to human development in Sri Lanka has been vastly exaggerated and that the country's unusually high level of human development owes more to favourable initial conditions than to policy - a view that has been hotly contested by others and now stands discredited. For a comprehensive review of this debate, see Osmani (1994).
} 
Figure 2: Trend of child undernutrition in South Asia (prevalence of stunting among children under five; \%)

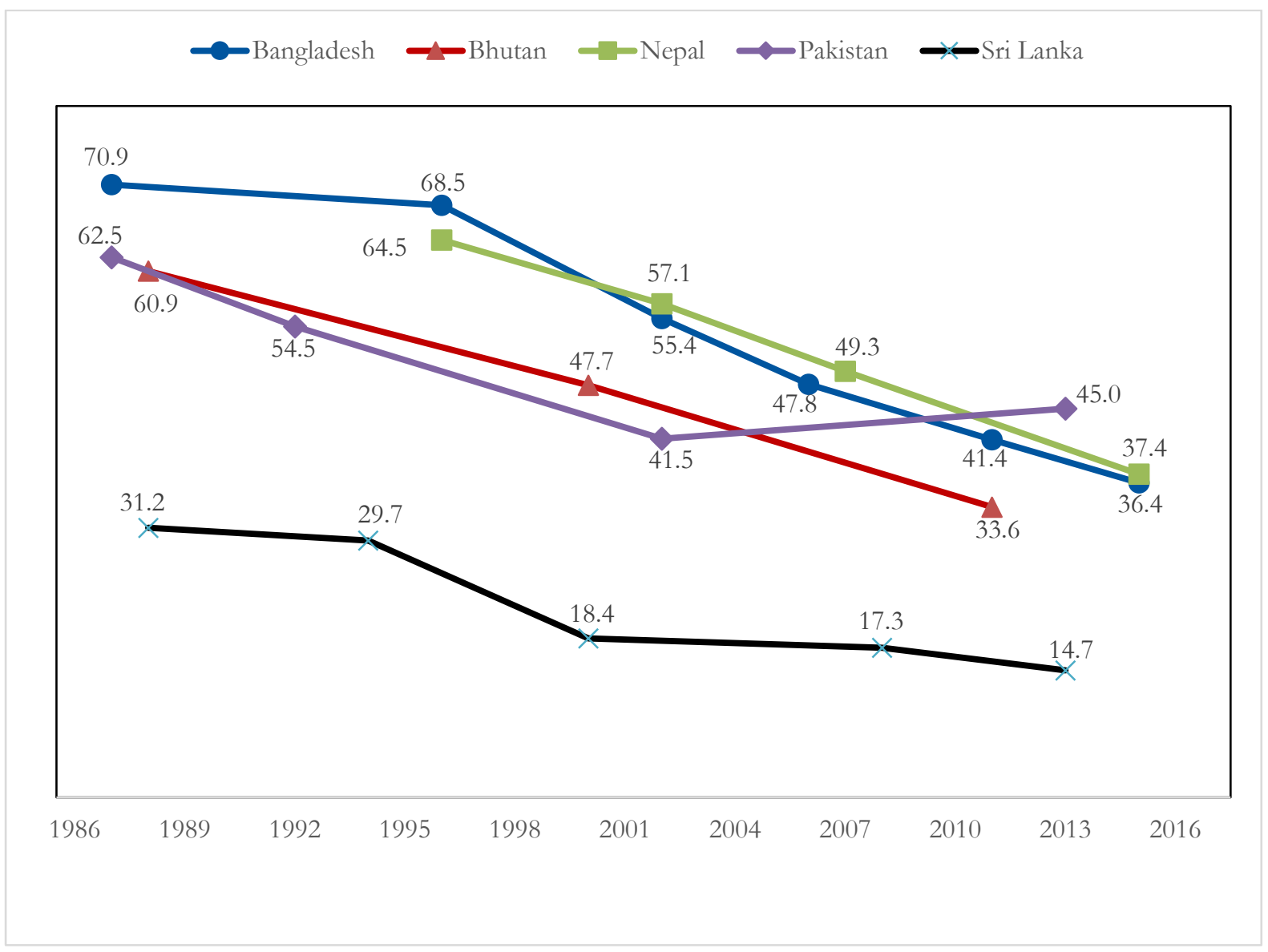

Source: World Bank's World Development Indicators (WDI) database.

South Asia (including India) has historically been notorious for having an exceptionally high prevalence of malnutrition, even compared with regions such as Sub-Saharan Africa, which have been economically more backward in most respects than South Asia. In the mid-1990s, UNICEF coined the term 'Asian Enigma' to refer to this perverse scenario. Much has changed in the two decades since then. While the level of malnutrition is still unacceptably high in all South Asian countries (with the exception of Sri Lanka), the speed of improvement has been quite remarkable. The sharpest decline has occurred in Bangladesh, where the prevalence of stunting has come down from around 69 per cent in 1995 to just 36 per cent in 2014. Nepal has also achieved rapid improvement, followed closely by Bhutan. Sri Lanka, which had less than half the stunting rate of the other countries to begin with, has been able to reduce it further-to just 15 per cent by 2014 . Pakistan is the sole exception to this pattern of sustained improvement. Some improvement did occur until the early 2000s, but there seems to have been a reversal since then. Poor progress in human development in Pakistan is underlined by low public spending on social sectors, which has actually declined as a share of GDP in recent years.

At the opposite end of the spectrum of progress in human development lies Bangladesh. In relation to the low- and lower-middle-income countries of the world, Bangladesh's performance in health and education makes it a significant outlier - with a much better performance than might be predicted on the basis of per capita income alone. What is more, Bangladesh has been able to achieve these results with a much lower public expenditure on health and education (as a percentage of GDP) than countries with comparable performance. This unique feature of Bangladesh's achievement reflects to a large extent the sterling role that its NGO community has 
played in promoting social development-much more than in any other part of South Asia (Asadullah et al. 2014).

One aspect of the NGO movement in Bangladesh that is especially salient in this context is its singular focus on women's empowerment. Since its very inception, the microfinance movement, led by the Grameen Bank, has targeted women as the main beneficiaries. BRAC, the largest development NGO in the world, has also kept women in the centre of its wide-ranging activities, involving microcredit, health, education, and entrepreneurship development. Most other NGOs have similarly engaged in women-focused activities. The Government of Bangladesh has also made a major contribution in this regard by giving special incentives to girls' education through stipends-first at primary and subsequently at secondary level. All these actions have enabled Bangladesh to achieve gender parity in school much sooner than the rest of the countries (other than Sri Lanka) ${ }^{32}$; and the advancement in girls' education, coupled with the general empowerment of women, has in turn helped the country achieve exceptional performance in the fields of health and nutrition despite low public spending in these areas.

While the region as a whole can be proud of the overall progress in human development that has taken place in the last two to three decades, a number of concerns are beginning to appear on the horizon. As these economies move on to the next stage of development and brace themselves to face the challenges of global competition on the one hand and rapid technological change on the other, they will need to improve the skill base of their population. While some improvement has indeed occurred, it has been from a very low base, and the current level of human capital among the countries' labour forces is still very low by international standards. One indication of this is the low ratio of young people with access to tertiary education, which has been in the range of 10-18 per cent in recent years (Figure 3).

Figure 3: Progress in tertiary education in South Asia (\% of gross enrolment)

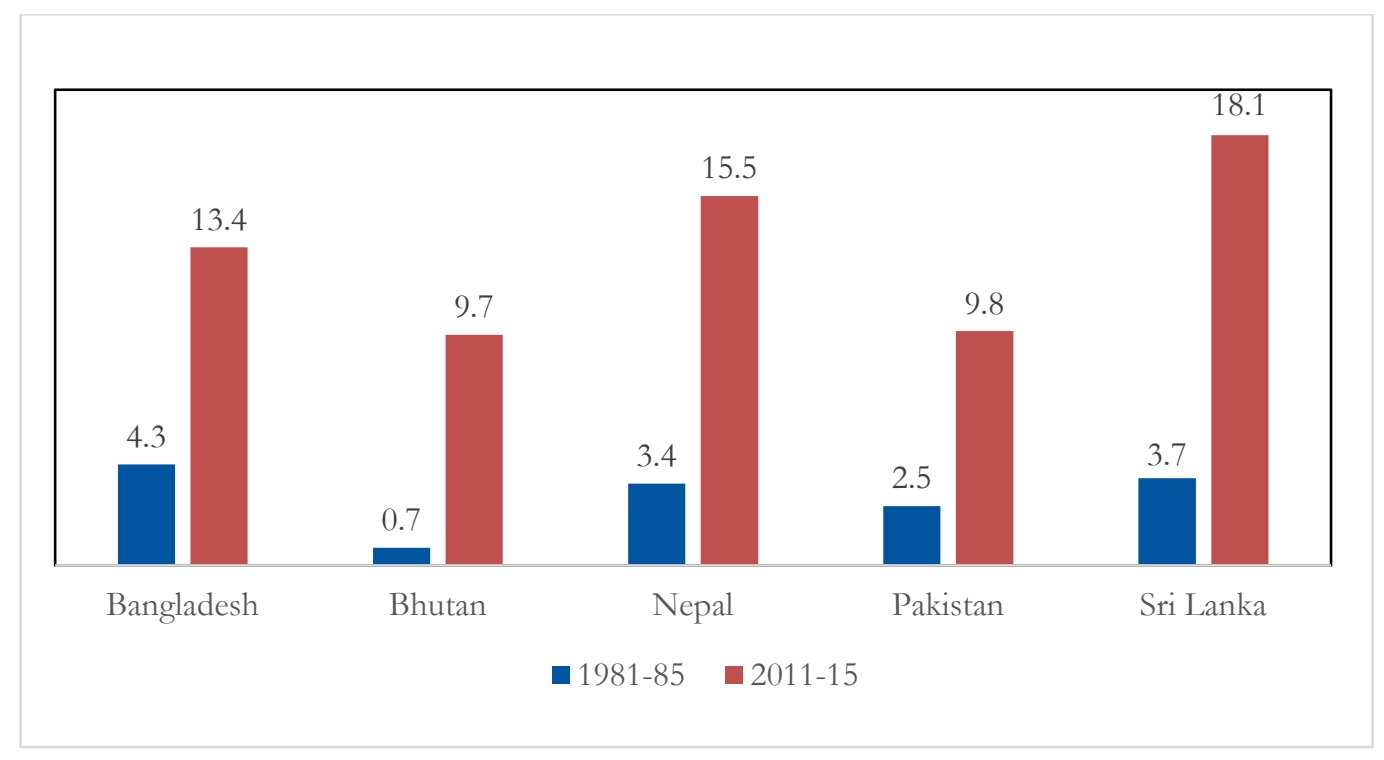

Source: World Bank's World Development Indicators (WDI) database.

Another, related, concern is rising inequality in various dimensions. Income inequality, as measured by the Gini coefficient, is generally on an upward trend in most of the countries (Figure 4). The

\footnotetext{
${ }^{32}$ Pakistan is the only country in the region (including India) which has yet to achieve gender parity in schooling; in fact, its gender parity index still hovers around just 50 per cent.
} 
upward-rising first half of Kuznets' celebrated inverted U-shaped relation between growth and inequality is evident for all countries except Sri Lanka, where the second, downward-sloping, part has begun to emerge in recent years- thanks to the deliberately egalitarian policies pursued by the present regime.

Figure 4: Trend of income inequality in South Asia (Gini coefficient)

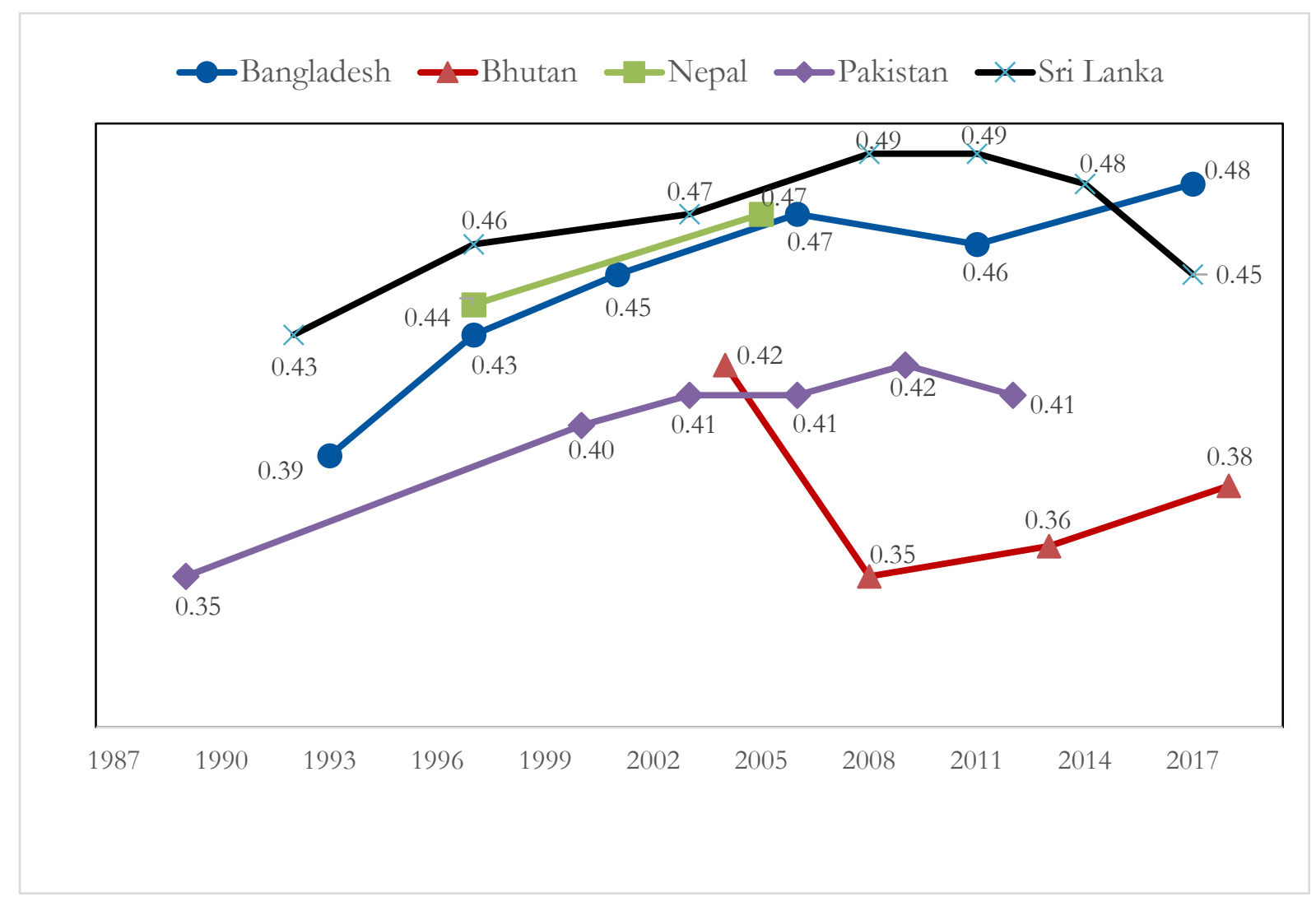

Note: The Gini coefficients measure inequality of income in all cases except Bhutan, for which they refer to expenditure distribution, as no information is available on income Gini.

Source: Osmani (2017) for Bangladesh; Dhungel (2009) for Nepal; Poverty Analysis Report (various years) by the National Bureau of Statistics of the Royal Government of Bhutan for Bhutan; Jamal (2014) for Pakistan; and reports on Household Income and Expenditure Surveys (various years) by the Department of Census and Statistics, Government of Sri Lanka, for Sri Lanka.

There are signs of growing inequality also in educational and health outcomes. It was noted earlier that the current level of human capital is generally low across the region. What makes the situation more worrisome is that, for the countries for which information on the distribution of human capital is available, it is the children from richer families that are acquiring an increasing share of whatever human capital is being formed. For instance, the difference in access to tertiary education between the richest and the poorest quintiles of the population has widened considerably since the early 1990s in Bangladesh, Nepal, and Pakistan (Table A3). The difference between the richest and the poorest quintiles in the prevalence of child malnutrition has also widened during the same period (Table A4). If unchecked, this trend of increasing inequality in human capital is likely to perpetuate income inequality through the inter-generational transmission mechanism; as children from poorer families accumulate less human capital and earn less income than children from richer families, they would transmit the inequality to the next generation. In the process, not only would 
inequality be perpetuated, but persistent inequality might also weaken the foundations of longterm growth. ${ }^{33}$

There is a good deal of commonality in the experience across the region, especially in the trends since the 1990s - as seen in the significant reduction in poverty and sharp improvement in various dimensions of human development in most of the countries, accompanied, however, by rising inequality. The notable exception is Pakistan, where, although poverty levels have declined, thanks largely to a spectacular growth in workers' remittances, human development has lagged behind badly. The contrast in this sphere between Pakistan on the one hand and Sri Lanka and Bangladesh on the other is quite stark. Sri Lanka has of course always been a leader in the field of human development in the region because of its singular emphasis on a welfare state since the early days, but in terms of rate of improvement Bangladesh's performance has been the most spectacular. Its achievement has been based on the twin foundations of an active government, supported by increasing availability of resources made possible by steady growth, and a uniquely active role of the NGO community. Pakistan, in contrast, has been hamstrung in both respects-public expenditure on human development has been thoroughly inadequate in the face of frequent collapses in economic growth, and NGO activism has been one of the weakest in the region.

\section{$7 \quad$ Challenges ahead}

South Asia has overcome many challenges in the last 50 years, and achieved significant improvement in the living standards of the people, defying the dire predictions of many. It could be argued, though, that perhaps the region was unable to realize its full potential, and there is also no doubt that many more challenges lie ahead. Many of the challenges are common, but some matter more for some countries than for others.

The situation is perhaps most challenging in Pakistan, where political uncertainty, weak governance, widespread terrorism, a high fertility rate, and a generally conservative attitude towards female education and female labour force participation combine to create an onerous set of constraints. Especially disconcerting is the fact that long-run growth potential is declining in Pakistan. It has been estimated that in the last 50 years Pakistan's annual GDP growth rate has fallen from 6 per cent to about 4.5 per cent (Lopez-Calix et al. 2012). A long-term decline in total factor productivity has been blamed principally for this decline in the country's growth potential. The current trend rate of 4.5 per cent is much lower than the 7 per cent the government estimates is needed to engage a bulging young population in gainful employment (Government of Pakistan 2011). This contrast between potential growth and warranted growth portends an ominous future for Pakistan, regardless of the political regime that comes to prevail, unless necessary structural reforms are undertaken immediately to reverse the decline in potential growth. ${ }^{34}$

Sri Lanka started its journey with the most favourable initial conditions, which have helped the country to maintain a fair rate of economic and social advancement despite prolonged and destructive ethnic conflicts, but for it to emerge fully from the legacies of the conflict and achieve its full potential remains a huge challenge. A matter of concern here is the recent political backlash that has tilted the policy regime aggressively towards restrictive and inward-looking economic policies. It does not augur well that recent trade policy has rendered the country's import regime

\footnotetext{
${ }^{33}$ For a fuller analysis of the inter-generational transmission mechanism—in the specific context of Bangladesh—see Osmani (2017).

${ }^{34}$ See Burki and Hasan (2013) for an insightful discussion of the kind of reforms needed.
} 
one of the most complex and protectionist in the world and that the consequent anti-export bias of the trade regime saw the trade ratio to plummet from 89 per cent of GDP in 2000 to just 48 per cent in 2016. The future success of Sri Lanka's economic performance will depend crucially on how well the politicians can combine the demands of populism with the needs of economic dynamism.

Nepal and Bhutan have found their own unique ways to overcome the inherent constraints of a land-locked economy that is dependent on a big neighbour. The excessive reliance on hydropower in Bhutan and on remittances in Nepal is creating a one-dimensional economy in each case, which is engendering a set of structural constraints that inhibit economic diversification and thereby limit the prospects of sustaining, let alone accelerating, the pace of socio-economic development. ${ }^{35}$

Bangladesh is perhaps the most favourably placed country within the region, and is most likely to be able to sustain a relatively rapid pace of socio-economic development in the coming decades. But in order to achieve its potential, the country will have to find ways of vastly improving its notoriously weak governance structure and lingering political uncertainty, which have led to stagnation in private investment in recent years.

In addition to these country-specific problems, the region as a whole faces a set of common challenges:

a) A low skill-base, which is utterly inadequate in the face of the emerging challenges of global competition and technological upheaval;

b) Rising inequality in multiple dimensions, which threatens to weaken the foundations of long-term growth, in addition to being unjust in itself;

c) Excessive reliance on workers' remittances, which could jeopardize the sustainability of the region's economic achievements owing to growing uncertainty in the oil economies of the Middle East, the rise of nationalistic sentiments in several industrialized economies, and the emergence of new suppliers of labour such as Viet Nam, Cambodia, and Laos;

d) Slowness in creating enough high-quality jobs, which not only constrains growth but also renders growth less effective in reducing poverty (Nayar et al. 2012);

e) Rapid urbanization, whose unique challenges none of the countries has yet to come to terms with.

Furthermore, the global problem of climate change will have far-reaching implications for the living standards of the region's people, as might changes in global geo-political alignments-with implications for trade flows and the flow of capital. The future trajectory of socio-economic development in the region will depend to a large extent on precisely how the political regimes respond to these emerging challenges.

\footnotetext{
${ }^{35}$ For a perceptive analysis of how excessive reliance on hydropower is creating serious structural imbalances for Bhutan, see World Bank (2015a).
} 


\section{References}

ADB (2013). Bhutan: Critical Development Constraints. Manila: Asian Development Bank.

ADB (2014). 'Poverty Analysis (Summary)'. Background paper for the Bhutan Country Partnership Strategy 2014-18. Manila: Asian Development Bank.

Ahmad, M., and R. Laporte (1989). Public Enterprise in Pakistan: The Hidden Crisis in Economic Development. Boulder, CO: Westview Press.

Asadullah, M.N., A. Savoia, and W. Mahmud (2014). 'Paths to Development: Is there a Bangladesh Surprise?’ World Development, 62 (October): 138-54.

Athukorala, P., and S. Jayasuriya (1994). Macroeconomic Policies, Crises, and Growth in Sri Lanka, 196990. Washington, DC: World Bank.

Athukorala, P., and S. Rajapathirana (2000). Liberalization and Industrial Transformation: Sri Lanka in International Perspective. Oxford: Oxford University Press.

Bhutto, Z.A. (1968). 'Political Situation in Pakistan: A Pamphlet'. Available at: https://www.bhutto.org/1966-1969_speech14.php (accessed 6 September 2018).

Burki, S.J. (1980). State and Society in Pakistan 1971-77. London: Macmillan.

Burki, S.J., and P. Hasan (2013). 'A Growth and Adjustment Strategy for Pakistan'. Policy Paper Series for Pakistan. Islamabad: World Bank.

Dhungel, K.R. (2009). 'Three Dimensions of Income Distribution, Poverty and Inequality'. The Himalayan Times, 8 October. Available at: https://thehimalayantimes.com/opinion/threedimensions-income-distribution-poverty-and-inequality/ (accessed 6 September 2018).

Government of Pakistan (2011). The Framework of Economic Growth. Planning Commission, Government of Pakistan.

Gunatilaka, R., G. Wan, and S. Chatterjee (2009). Poverty and Human Development in Sri Lanka. Manila: Asian Development Bank.

Hasan, P. (2008). 'Pakistan'. In A. Chowdhury and W. Mahmud (eds), Handbook on the South Asian Economies. London: Edward Elgar.

Jamal, H. (2014). 'Growth and Income Inequality Effects on Poverty: The Case of Pakistan (19882011)'. Social Policy and Development Centre: Islamabad. Available at: https:/ / mpra.ub.unimuenchen.de/59897/ (accessed 3 September 2018).

Kelegama, S. (2008). 'Sri Lanka'. In A. Chowdhury and W. Mahmud (eds), Handbook on the South Asian Economies. London: Edward Elgar.

López-Cálix, J.R., T.G. Srinivasan, and M. Waheed (2012). What Do We Know About Growth Patterns in Pakistan? Policy Paper Series for Pakistan. Islamabad: World Bank.

Lopez-Calix, J.R., C. Mejia, D. Newhouse, and C. Sobrado (2014). Pakistan Poverty Trends, Scenarios and Drivers. Policy Paper Series for Pakistan. Islamabad: World Bank.

Mahat, R.S. (2018). 'Economic Reforms in South Asia with Special Reference to Nepal'. (Mimeo.) Keynote speech delivered at the 15th Annual Conference of the South Asian Network of Economics Research Institutes (SANEI) in Kathmandu, Nepal.

Mahmud, W. (2004). 'Macroeconomic Management: From Stabilisation to Growth?' Economic and Political Weekly, 4 September: 4023-32.

Mahmud, W., and S.R. Osmani (2016). The Theory and Practice of Microcredit. London: Routledge. 
Nayar, R., P. Gottret, P. Mitra, G. Betcherman, Y.M. Lee, I. Santos, M. Dahal, and M. Shrestha (2012). More and Better Jobs for South Asia. Washington, DC: World Bank.

NSB (2014). Bhutan Poverty Assessment 2014. Thimphu: National Statistical Bureau of the Royal Government of Bhutan and World Bank.

Osmani, S.R. (1994). 'Is there a Conflict between Growth and Welfarism? The Significance of the Sri Lanka Debate'. Development and Change, 25(2): 387-421.

Osmani, S.R. (2009). 'Explaining Growth in South Asia'. In G. McMahon, H. Esfahani, and L. Squire (eds), Diversity in Economic Growth: Global Insights and Explanations. Cheltenham: Edward Elgar.

Osmani, S.R. (2017). 'Eradicating Poverty and Minimizing Inequality for Ensuring Shared Prosperity in Bangladesh'. (Mimeo.) A background paper prepared for the Perspective Plan 2021-41 of the Planning Commission of the Government of Bangladesh: Dhaka.

Osmani, S.R., and B.B. Bajracharya (2008). 'Nepal'. In A. Chowdhury and W. Mahmud (eds), Handbook on the South Asian Economies. London: Edward Elgar.

Osmani, S.R., B.B. Bajracharya, S. Tenzing, and T. Wangyal (2005). Macroeconomics of Poverty Reduction: The Case Study of Bhutan. A report prepared for the UNDP regional project on the Macroeconomics of Poverty Reduction. Colombo: UNDP Regional Centre.

Osmani, S.R., W. Mahmud, B. Sen, H. Dagdeviren, and A. Seth (2006). The Macroeconomics of Poverty Reduction: The Case Study of Bangladesh. Colombo: UNDP Regional Centre.

Osmani, S.R., S. Tenzing, and T. Wangyal (2008). 'Bhutan'. In A. Chowdhury and W. Mahmud (eds), Handbook on the South Asian Economies. London: Edward Elgar.

Pant, B.D., N.K. Joshi, and P. Rijal (eds) (2017). Selected Essays on Nepali Economy. Kathmandu: Institute for Integrated Development Studies.

Raihan, S., S.R. Osmani, and M.A.B. Khalily (2017). 'The Macro Impact of Microfinance in Bangladesh: A CGE Analysis'. Economic Modelling, 62(April): 1-15.

Royal Government of Bhutan (1999). Vision 2020: A Vision for Peace, Prosperity and Happiness. Thimphu: Planning Commission, Royal Government of Bhutan.

Sen, B., and Z. Ali (2017). 'Ending Extreme Poverty in Bangladesh: Trends, Drivers, and Policies'. In J. Devine, G.D. Wood, Z. Ali, and S. Alam (eds), Extreme Poverty, Growth and Inequality in Bangladesh. Rugby, UK: Practical Action Publishing.

Sobhan, R., and M. Ahmad (1980). Public Enterprise in an Intermediate Regime. Dhaka: Bangladesh Institute of Development Studies.

Uematsu, H., A.R. Shidiq, and S. Tiwari (2016). 'Trends and Drivers of Poverty Reduction in Nepal: A Historical Perspective.' Policy Research Working Paper 7830. Washington, DC: World Bank.

World Bank (2013). Bangladesh Poverty Assessment: Assessing a Decade of Progress in Reducing Poverty, 2000-2010. Dhaka: World Bank.

World Bank (2014). Kingdom of Bhutan: Green Growth Opportunities for Bhutan (Policy Note). Washington, DC: World Bank.

World Bank (2015a). Hydropower Impact and Public Finance Reforms towards Economic Self-Reliance. Bhutan-Macroeconomic and Public Finance Policy Note. Washington, DC: World Bank.

World Bank (2015b). Sri Lanka: Ending Poverty and Promoting Shared Prosperity. Washington, DC: World Bank. 
World Bank (2016a). Moving Up the Ladder: Poverty Reduction and Social Mobility in Nepal. Kathmandu: World Bank.

World Bank (2016b). Sri Lanka Poverty and Welfare: Recent Progress and Remaining Challenges. Washington, DC: World Bank.

World Bank (2017). Climbing Higher: Toward a Middle Income Nepal. Washington, DC: World Bank. 


\section{Appendix}

Table A1: Long-term trend of some development indicators of South Asia: 1961-65 to 2010-15 (annual average figures for the respective periods)

\begin{tabular}{|c|c|c|c|}
\hline Indicator & 1961-65 & 2010-15 & $\begin{array}{c}\text { Factor of } \\
\text { change }\end{array}$ \\
\hline \multicolumn{4}{|l|}{ Population (million) } \\
\hline Bangladesh & 52.6 & 157.6 & 3.0 \\
\hline Bhutan & 0.2 & 0.8 & 3.2 \\
\hline Nepal & 10.6 & 28.0 & 2.7 \\
\hline Pakistan & 48.4 & 181.7 & 3.8 \\
\hline Sri Lanka & 10.7 & 20.6 & 1.9 \\
\hline \multicolumn{4}{|c|}{ Population growth (\% per year) } \\
\hline Bangladesh & 2.9 & 1.2 & 0.4 \\
\hline Bhutan & 2.6 & 1.6 & 0.6 \\
\hline Nepal & 1.6 & 1.2 & 0.7 \\
\hline Pakistan & 2.5 & 2.1 & 0.8 \\
\hline Sri Lanka & 2.4 & 0.8 & 0.3 \\
\hline \multicolumn{4}{|c|}{ Fertility rate (births per woman) } \\
\hline Bangladesh & 6.9 & 2.2 & 0.32 \\
\hline Bhutan & 6.7 & 2.2 & 0.33 \\
\hline Nepal & 6.0 & 2.3 & 0.39 \\
\hline Pakistan & 6.6 & 3.7 & 0.56 \\
\hline Sri Lanka & 5.1 & 2.1 & 0.42 \\
\hline \multicolumn{4}{|c|}{ GDP per capita (2010 US\$) } \\
\hline Bangladesh & 392 & 882 & 2.2 \\
\hline Bhutan* & 426 & 2,445 & 5.7 \\
\hline Nepal & 274 & 649 & 2.4 \\
\hline Pakistan & 344 & 1,088 & 3.2 \\
\hline Sri Lanka & 594 & 3,368 & 5.7 \\
\hline \multicolumn{4}{|c|}{ Life expectancy at birth (years) } \\
\hline Bangladesh & 47 & 70 & 1.5 \\
\hline Bhutan & 35 & 69 & 2.0 \\
\hline Nepal & 36 & 68 & 1.9 \\
\hline Pakistan & 48 & 65 & 1.4 \\
\hline Sri Lanka & 59 & 71 & 1.2 \\
\hline \multicolumn{4}{|c|}{ Primary enrolment rate (\% gross) $)^{\star \star}$} \\
\hline Bangladesh & 63.6 & 117.7 & 1.9 \\
\hline Bhutan & 21.7 & 107.3 & 4.9 \\
\hline Nepal & 39.0 & 139.4 & 3.6 \\
\hline Pakistan & 50.8 & 91.9 & 1.8 \\
\hline Sri Lanka & 94.8 & 100.7 & 1.1 \\
\hline
\end{tabular}

Notes: * The initial period for Bhutan's GDP per capita is $1980-81 . * *$ The initial period for primarily enrolment is 1970-75 for all countries.

Source: World Bank's World Development Indicators (WDI) database. 
Table A2: Initial conditions: 1961-65

\begin{tabular}{|c|c|c|c|c|c|c|}
\hline & $\begin{array}{l}\text { GDP per capita } \\
\text { (2010 US\$) }\end{array}$ & $\begin{array}{c}\text { Share of } \\
\text { manufacturing in } \\
\text { GDP (\%) }\end{array}$ & $\begin{array}{l}\text { Population } \\
\text { (million) }\end{array}$ & $\begin{array}{c}\text { Population } \\
\text { density } \\
\text { (person/sq km) }\end{array}$ & $\begin{array}{l}\text { Life expectancy } \\
\text { at birth } \\
\text { (years) }\end{array}$ & $\begin{array}{c}\text { Gross enrolment } \\
\text { at primary level } \\
(\%)\end{array}$ \\
\hline Bangladesh & 392 & 5.4 & 52.6 & 404 & 47 & 63.6 \\
\hline Bhutan & $\mathrm{n} / \mathrm{a}$ & $\mathrm{n} / \mathrm{a}$ & 0.2 & 5 & 35 & 21.7 \\
\hline Nepal & 274 & 3.3 & 10.6 & 74 & 36 & 39.0 \\
\hline Pakistan & 344 & 14.1 & 48.4 & 63 & 48 & 50.8 \\
\hline Sri Lanka & 594 & 16.5 & 10.7 & 170 & 59 & 94.8 \\
\hline India & 322 & 17.1 & 477.8 & 161 & 44 & 80.8 \\
\hline East Asia \& Pacific & 270 & 29.6 & 932.0 & 59 & 48 & 105.9 \\
\hline Sub-Saharan Africa & 1,150 & $n / a$ & 245.6 & 10 & 42 & 56.1 \\
\hline Latin America \& Caribbean & 3,822 & 24.9 & 224.5 & 12 & 57 & 105.6 \\
\hline Middle East \& North Africa & 1,880 & $n / a$ & 106.0 & 12 & 48 & 75.0 \\
\hline
\end{tabular}

Notes: (1) Economic data are not available for Bhutan until 1980. (2) Primary enrolment figures relate to 1970-74; all others to 1961-65.

Source: World Bank's World Development Indicators (WDI) database. 
Table A3: Inequality in nutritional status (rate of stunting among children under five; \%)

\begin{tabular}{lcccccc}
\hline \multicolumn{2}{c}{ Wealth quintiles } & \multicolumn{2}{c}{ Bangladesh } & \multicolumn{2}{c}{ Nepal } & \multicolumn{2}{c}{ Pakistan } \\
& 1997 & 2014 & 1996 & 2016 & $1990 / 91$ & 2013 \\
\hline Quintile 1 & 65.3 & 49.2 & 64.5 & 49.2 & 64.4 & 61.6 \\
Quintile 2 & 68.5 & 42.2 & 61.0 & 38.7 & 62.0 & 55.7 \\
Quintile 3 & 63.6 & 35.9 & 58.1 & 35.7 & 58.2 & 40.6 \\
Quintile 4 & 57.7 & 31.0 & 52.2 & 32.4 & 52.7 & 37.8 \\
Quintile 5 & 40.2 & 19.4 & 39.8 & 16.5 & 38.6 & 23.0 \\
\hline
\end{tabular}

Source: Data from Demographic and Health Surveys (DHS) as reported in World Bank's World Development Indicators (WDI) database.

Table A4: Inequality in higher education (gross enrolment in tertiary education: \%)

\begin{tabular}{lcccccc}
\hline \multirow{2}{*}{ Wealth quintiles } & \multicolumn{2}{c}{ Bangladesh } & \multicolumn{2}{c}{ Nepal } & \multicolumn{2}{c}{ Pakistan } \\
& 1993 & 2011 & 1996 & 2011 & 1990 & 2012 \\
\hline Quintile 1 & 0.0 & 3.2 & 1.3 & 11.5 & 0.1 & 2.6 \\
Quintile 2 & 0.9 & 12.9 & 0.9 & 16.6 & 0.2 & 8.6 \\
Quintile 3 & 3.3 & 20.8 & 2.4 & 27.1 & 0.6 & 13.5 \\
Quintile 4 & 11.4 & 28.1 & 4.1 & 48.2 & 1.8 & 20.4 \\
Quintile 5 & 29.2 & 43.0 & 18.8 & 72.8 & 8.8 & 41.4 \\
\hline
\end{tabular}

Source: Data from Demographic and Health Surveys (DHS) as reported in World Bank's World Development Indicators (WDI) database. 